\title{
INTEGRASI NILAI-NILAI PENDIDIKAN KARAKTER PADA SETIAP MATA PELAJARAN DI TINGKAT SMPN (Studi pada Lingkup Dinas Pendidikan Kabupaten Bulukumba)
}

\author{
Oleh: \\ SUKRI BADARUDDIN \\ Sekolah Tinggi Agama Islam Negeri (STAIN) Majene \\ e-mail: sukribadaruddin@stainmajene.ac.id
}

\begin{abstract}
ABSTRAK: Bahwa pendidikan karakter sangat strategis dan utama dalam sistem pendidikan nasional sebagai usaha membina karakter para peserta didik yang berbasis nilai-nilai dasar negara pancasila dana nilai-nilai kebangsaan Indonesia, termasuk di dalamnya tercakup nilai-nilai kearifan lokal serta nilai-nilai alkulturasi yang berkembang dan yang mendukung pembinaan karakter peserta didik khususnya pada tingkat SMPN. Hal tersebut harus menjadi perhatian utama bagi para guru pemangku mata pelajaran yang mengintegrasikan materi pendidikan karakter, sehingga dalam penyusunan konsep materi ajar berisi nilai pendidikan karakter yang relevan dan sesuai dengan mata pelajaran. Rumusan masalah yang dikaji dalam penelitian ini (1) bagaimana kondisi pengembangan materi ajar pendidikan karakter oleh para guru SMPN di kabupaten Bulukumba?; (2) bagaimana tingkat kemampuan guru dalam pengembangan materi ajar, pemilihan sumber, strategi, model dan evaluasi yang diterapkan dalam pembelajaran pendidikan karakter? Tujuan penelitian ini adalah (i) untuk mengetahui kondisi pengembangan materi ajar pendidikan karakter oleh para guru SMPN; (ii) untuk mendapatkan data dan informasi tentang kemampuan guru dalam mengembangkan materi ajar, pemilihan sumber bahan ajar, strategi, model dan evaluasi pembelajaran pendidikan karakter pada tingkat SMPN. Penelitian Ini menggunakan pendekatan/metode deskriptif kualitatif, dengan teknik pengumpulan data, observasi, koesioner, wawancara dan fokus group discusssion. Hasil penelitian menunjukkan bahwa: (1) Kemampuan para guru MP yang menintegrasikan materi pend. karakter cukup memadai, dan mampu meramu bahan ajar dari bahan literasi dan nilai-nilai kearifan lokal setempat; (2) tingkat kemampuan MP dalam mengintegrasikan materi ajar pend. karakter tergolong tinggi dan secara teknis oprasional implementasi pembelajaran pend. karakter para guru MP masih menemui kesulitan terutama dalam merumuskan spesifikasi subtansi perumusan desain pembelajaran materi ajar pend. karakter pada tingkat SMPN.
\end{abstract}

\section{KATA KUNCI: Integrasi, Materi ajar, Pendidikan Karakter}

ABSTRACT: That character education is very strategic and mandatory in the national education system as an effort to foster students' character on the basis of the fundamental values of Pancasila and the national values, comprising the values of local wisdom and acculturation which are flourishing and encouraging students' character development, particularly the middle school level is justified. This should be primely taken into account by teachers who integrate the character education teaching materials, so the preparation of the concept of teaching materials holds the value of character education that is relevant and in accordance with the given subject. The examined problem questions in the study are (1) what are conditions in developing the character education materials by middle school teachers in Bulukumba?; (2) what is the teachers' ability in developing materials, selecting the source of the materials, and determining startegies, models, and evaluation 
implemented in character education teaching?. The aims of the study are to find out the conditions in developing the character education materials by middle school teachers in Bulukumba; (ii) to acquire the data and information about teachers' ability in developing materials, selecting the source of the materials, and determining startegies, models, and evaluation implemented in character education teaching in middle school level. The study employs qualitative descriptive approach with observation, questionnaires, interviews, focused group discussions as the data collection techniques. The findings showed; (1) that the teachers' ability in the given subject who integrated the character education materials were satisfactory, and the teachers were able to design the materials based on literacy sources and local wisdom values; (2) the degree of teachers' ability in implementing character education teaching materials was classified as high, and technically, the teachers still encountered issues in the operational implementation of character education teaching, especially in formulating the substantial specification conceiving the design of character education teaching materials in the middle school level.

KEYWORDS: Integration, Teaching materials, Character Education

\section{PENDAHULUAN}

Bidang pendidikan adalah salah satu bidang dan sektor pembangunan nasional yang sangat strategis, urgen dan menjadi kunci utama lahirnya manusiamanusia Indonesia yang unggul. Bidang pendidikan menyiapkan sumber daya manusia Indonesia yang mampu mandiri, unggul dan bersaing dengan bangsa lain. Kualitas sumber daya manusia sangat tergantung dari kualitas isi pendidikan nasional disemua jenjang dan tingkatan pendidikan.

Dalam Undang-undang nomor 20 tahun 2003 tentang Sistem Pendidikan Nasional, pada pasal 3 ditegaskan bahwa pendidikan nasional berfungsi mengembangkan kemampuan dan membentuk watak serta peradaban bangsa yang bermartabat dalam rangka mencerdaskan kehidupan bangsa, bertujuan untuk berkembangnya potensi peserta didik agar menjadi manusia yang beriman dan bertaqwa kepada Tuhan Yang Maha Esa berakhlak mulia, sehat, berilmu, cakap, kreatif, mandiri dan menjadi warga negara yang demokratis serta bertanggung jawab. Selanjutnya dalam pasal 4 dari Undang-undang tersebut pada poin 3 dan 4 dijelaskan bahwa prinsip penyelenggaraan pendidikan adalah sebagai suatu proses pembudayaan dan pemberdayaan peserta didik yang berlangsung sepanjang hayat, dan diselenggarakan dengan memberi keteladanan, membangun kemauan dan mengembangkan kreativitas peserta didik dalam proses pembelajaran.

Untuk menjamin terselenggaranya pendidikan nasional secara terarah, tertib terukur dan terkendali mutunya, maka Departemen Pendidikan Nasional menerbitan peraturan pemerintah nomor 32 tahun 2013, yang mengatur tentang Standar Pendidikan Nasional dimana salahsatu butirnya diatur mengenai Standar Isi pendidikan nasional yang bersangkutpaut dengan kriteria mengenai ruang lingkup materi dan tingkat kompetensi untuk mencapai kompetensi lulusan pada jenjang dan jenis pendidikan tertentu.

Bagian terpenting dan utama dari isi/materi pendidikan adalah pendidikan karakter atau pendidikan berintegritas yang dalam kurikulum belum semua aspek dan indikator dirumuskan secara sistematis dan utuh.

Perbincangan tentang pendidikan karakter saat ini menjadi hangat dan mendapatkan perhatian utama dari 
kalangan pendidik, pemerhati pendidikan dan bahkan semua stake holders pendidikan secara luas. Sikap, pola pikir dan kesadaran berperilaku warga negara Indonesia (umumnya generasi muda) cenderung mengabaikan nilai-nilai pendidikan karakter. Gejala-gejala yang sangat tampak bagi kita dalam kehidupan keseharian fenomena kita saksikan seperti perbuatan korupsi, penyebaran kabar bohong (hoax), intoleransi, kurang menghargai, bentuk-bentuk kekerasan, sindiran penodaan, memudarnya keadaban publik, fenomena begal, kurang penghormatan atas institusi negara, gaya hidup instan, dan sebagainya, semuanya menjadi bukti pragmatis betapa pendidikan karakter harus ditegakkan terutama di sekolah-sekolah dengan melakukan reorientasi, reorganisasi dan redesain program kurikulum dan pembelajaran agar benar-benar selaras, seimbang dan searah dengan nilai-nilai luhur bangsa Indonesia.

Generasi muda Indonesia harus dibangun di atas landasan falsafah dan kebudayaan Indonesia sendiri yaitu Pancasila, karena atas landasan ini heteroginitas, integritas dan kebinekaan Indonesia dapat dijembatani dengan nilainilai luhur bangsa Indonesia. Pendidikan karakter atau pendidikan berintegritas yang diberikan pada para peserta didik di sekolah, khususnya pada tingkat SMPN materi ajarnya diintegrasikan kedalam mata pelajaran tertentu. Pendidikan karakter harus menjadi basis pembinaan nilai-nilai keIndonesia masa kini dan masa mendatang.

Berdasaran latar belakang di atas, maka rumusan masalah penelitian ini adalah: (1) Bagaimana kondisi pengembangan materi ajar pendidikan karakter terintegrasi oleh para guru SMPN di Kabupaten Bulukumba? (2) Bagaimana tingkat kemampuan guru dalam penguasaan materi ajar, pemilihan sumber, strategi, metoda, model, media dan evaluasi yang diterapkan dalam pembelajaran pendidikan karakter terintegrasi?

\section{Hakekat dan Tujuan Pendidikan Karakter}

Pendidikan karakter merupakan usaha sadar untuk menanamkan nilainilai luhur/kebajikan (value-vertue) yang berupa nilai kemanusiaan dan nilai budaya yang dimiliki dan telah diyakini manfaat kebenarannya dalam masyarakat tertentu (Denda P. 1998). Pendidikan karakter lebih cenderung pada pembentukan dan pemodelan sikap dan perilaku manusia. Pendidikan karakter lebih banyak dilatihkan dan dicontohkan untuk diteladani daripada diajarkan secara konseptual teoritis. Pendidikan karakter lebih cenderung diwaranai oleh nilai nilai yang berbasis keluaarga, masyarakat dan nilai-nilai kenegaraan (Pancasila) sebagai basis utama,

Pendidikan karakter bertujuan meningkatkan aplikasi sikap dan perilaku mulia (Denda P, 1998). Sikap dapat mencerminkan pola pikir dan pola laku manusia (pola perilaku manusia) dengan mengamati reaksi seseorang akan dapat diketahui fenomena indikator sikap pada dirinya. Sikap seseorang berkaitan dengan tindakan nyata (Fhisbein \& Ajzan, 1974) salah satu fenomena yang paling meyakinkan dalam riset mutakhir tentang sikap adalah kenyataan bahwa tingkahlaku bisa juga mempengaruhi sikap, bukan hanya mencerminkan pandangan yang dipegang oleh orang tersebut sebelumnya (Festinger \& Carlsmith, 1959).

Zubaedi (2011), mengemukakan secara rinci lima tujuan pendidikan karakter yaitu : 1) Mengembangkan potensi kalbu/nurani/afektif peserta didik sebagai manusia dan warga negara yang memiliki nilai-nilai karakter; 2) mengembangkan kebiasaan dan perilaku peserta didik yang terpuji dan sejalan 
dengan nilai-nilai universal dan tradisi budaya bangsa yang religius; 3) menanamkan jiwa kepemimpinan dan tanggung jawab peserta didik sebagai generasi penerus bangsa; 4) mengembangkan kemampuan peserta didik menjadi manusia yang mandiri, kreatif dan berwawasan kebangsaan; 5) mengembangkan lingkungan kehidupan sekolah sebagai lingkungan belajar yang aman, jujur, penuh kreativitas, persahabatan, rasa kebangsaan yang tinggi dan penuh kekuatan.

\section{Materi/isi dan Sumber Pendidikan Karakter}

Pada dasarnya isi pendidikan karakter secara umum telah dijabarkan oleh pendiri republik Indonesia (the founding fathers) yang dijabarkan kedalam dokumen-dokumen resmi negara Indonesia seperti dalam Piagam Jakarta, pembukaan UUD 1945, Pancasila, dan UUD Negara Indonesia 1945. Tugas para pendidik adalah bagaimana menggali nilai-nilai dasar yang tersirat dalam naskah-naskah tersebut untuk dibuatkan butir-butir standar dan selanjutnya dikonfirmasikan dengan perkembangan nilai-nilai kemanusiaan dan keIndonesiaan dalam rangka membangun karakter (character building) warga negara Republik Indonesia. Tentunya konsep asimilasi, adopsi, akulturasi, konfirmasi, konsensus, dan komitmen untuk menyerap nilai-nilai dari luar tentu tidak bisa diabaikan dengan prinsip menerima apa adanya. Isi pendidikan karakter Indonesia harus berintikan nilai-nilai luhur bangsa Indonesia (Notonagoro, 1983).

Kesembilan butir isi pendidikan berintegritas tersebut adalah kejujuran, kepedulian, keadilan, disiplin, tanggung jawab, kemandirian, kerjakeras, sederhana, dan keberanian. Kesembilan nilai tersebut mencerminkan nilai-nilai inti kemanusiaan sikap dan etos yang mencerminkan kepribadian seseorang. Menurut Sumarno S (2004), setidaknya ada tiga nilai yang dimiliki manusia dalam jatidiri-kepribadiannya yang utuh yaitu ; a) nilai tersier, yang di didik, dibentuk dan dipengaruhi oleh lingkungan; b) nilai sekunder, yang diperoleh secara generatif; dan c) nilai primer, yang asli dikaruniakan Tuhan (Allah SWT) yang bersifat langgeng dan abadi.Materi pendidikan karakter sangat terkait dengan materi pembelajaran yang berdimensi filosofis keagamaan, akademik, sosio-kultural, sosio-ekonomi, normatif, adat istiadat atau kearifan lokal (local genius).

Kementerian Pendidikan Nasional telah mengidentifikasi dan melangsir bahwa berdasarkan kajian nilai-nilai agama, norma-norma sosial, peraturan/hukum, etika akademik dan prinsip-prinsip hak asasi manusia, telah teridentifikasi 80 butir nilai karakter yang dikelompokkan menjadi 5 golongan pokok nilai yaitu : a) nilai-nilai perilaku manusia yang berhubungan dengan Tuhan Yang Maha Esa; b) nilai-nilai perilaku manusia yang berhubungan dengan diri sendiri; 3) nilai-nilai perilaku manusia yang berhubungan sesama manusia; 4) nilai-nilai perilaku manusia yang berhubungan dengan lingkungan; 5) nilai-nilai perilaku manusia yang berhubungan dengan kebangsaan.

Selanjutnya Kemendiknas mengidentifikasi secara formal delapan belas nilai-nilai pendidikan karakter yang dipertimbangkan sebagai bagian dalam kurikulum sekolah untuk diajarkan dan ditanamkan pada para peserta didik, yaitu:

a. Religius, berupa sikap dan perilaku, patuh dalam melaksanakan ajaran agama yang dianutnya, toleran terhadap pelaksanaan ibadah agama lain serta hidup rukun dengan pemeluk agama lain; 
b. Jujur, berupa perilaku yang menunjukkan dirinya sebagai orang yang dapat dipercaya, konsisten terhadap ucapan dan tindakan sesuai dengan hati nurani;

c. Toleransi, berupa sikap tindakan yang menghargai perbedaan, baik perbedaan agama, suku, ras, sikap atau pendapat dirinya dengan orang lain;

d. Disiplin, berupa tindakan yang menunjukkan adanya kepatuhan, ketertiban terhadap ketentuan dan peraturan yang berlaku;

e. Kerja Keras, berupa perilaku yang menunjukkan upaya sungguhsungguh dalam menghadapi dan mengatasi berbagai hambatan belajar, tugas atau yang lainnya dengan sungguh-sungguh dan pantang menyerah;

f. Kreatif, berupa kemampuan olah pikir, olah rasa dan pola tindak yang dapat menghasilkan sesuatu yang baru dan inovatif;

g. Mandiri, berupa sikap dan perilaku dalam bertindak yang tidak tergantung pada orang lain dalam menyelesaikan sesuatu masalah atau tugas;

h. Demokratis, berupa cara berpikir, bersikap dan bertindak dengan menempatkan hak dan kewajiban yang sama antara dirinya dengan orang lain;

i. Rasa Ingin Tau, berupa sikap dan tindakan yang menunjukkan upaya untuk mengetahui lebih dalam tentang sesuatu hal yang dilihat, didengar dan dipelajari;

j. Semangat Kebangsaan, yaitu cara berfikir, bertindak dan cara pandang yang lebih mendahulukan kepentingan bangsa dan negara diatas kepentingan pribadi dan kelompok;

k. Cinta Tanah Air, berupa cara berfikir, bersikap dan bertindak yang menunjukan rasa kesetiaan yang tinggi terhadap bangsa dan negara;

1. Menghargai Prestasi, berupa sikap dan perilaku yang mendorong dirinya untuk secara ikhlas mengakui keberhasilan orang lain atau dirinya;

m. Bersahabat/komunikatif, berupa tindakan yang mencerminkan atau memperlihatkan senang dalam berbicara, bekerja atau bergaul dengan orang lain;

n. Cinta Damai, berupa sikap, perilaku dan perkataan atau perbuatan yang membuat orang lain merasa senang, tentram dan damai;

o. Gemar Membaca, berupa sikap atau kebiasaan meluangkan waktu untuk membaca buku-buku yang bermanfaat dalam hidupnya, baik untuk kepentingan sendiri atau orang lain;

p. Peduli Lingkungan, berupa sikap dan perilaku dan tindakan untuk menjaga, melestarikan dan memperbaiki lingkungan hidup;

q. Peduli Sosial, berupa sikap dan tindakan yang selalu memperhatikan kepentingan orang lain dalam hidup dan kehidupan;

r. Tanggung Jawab, berupa sikap dan perilaku seseorang yang ditunjukkan dalam melaksanakan tugas sesuai dengan kaidah-kaidah yang berlaku.

Adapun sumber-sumber materi ajar penididikan karakter tentu tidak terlepas dengan naskah-naskah kenegaraan sebagaimana dikemukakan di atas, dan naskah-naskah akademik teoritis yang berkembang sampai saat ini. Sumber materi ajar pendidikan karakter yang berisi nilai-nilai luhur dan berdimensi filosofis keagamaan, akademik, normatif, sosio-kultural, sosioekonomi, adat istiadat semuanya merupakan sumber materi ajar yang sangat utama dalam pembentukan dan pembinaan dalam membangun nilai-nilai kepribadian bangsa. Dari uraian di atas 
dapat dirunut dan ditarik beberapa poin besar tentang materi ajar pendidikan karakter atau pendidikan berintegritas yang meliputi; a) sikap dan perilaku keteladanan; b) nilai-nilai religius yang dianut oleh kaum tertentu; c) nilai teori dan konsep; d) nilai-nilai pancasila sebagai dasar negara dan ideologi negara; e) nilai-nilai dalam UUD 1945 dan nilai perundang-undangan yang berlaku; f) norma-norma adat kebiasaan yang tumbuh dan berkembang dalam masyarakat Indonesia; g) nilai-nilai dari seleksi asimilasi, akulturasi, adopsi, dan inovasi dari budaya kemanusiaan yang mulia; h) pola pikir sikap mulia dan perilaku positif yang bermanfaat daripara pahlawan, tokoh dan orang-orang yang senantiasa menunjukkan keteladanan dan akhlak mulia; i) sumber dari kajian nilainilai perilaku sikap dan kreativitas anak sebagai peserta didik dalam kesehariannya.

\section{Strategi Implementasi dan Evaluasi Pendidikan Karakter}

Pembelajaran adalah suatu usaha mengembangkan potensi setiap individu peserta didik (Dendosurono Prawiroadmodjo, 1984). Standar keberhasilan belajar peserta didik yang telah ditentukan untuk dicapai sangat ditentukan oleh kemampuan (ability) guru dalam mendesain strategi pendekatan dan model pembelajarannya. Dipahami bahwa belajar bukanlah semata-mata untuk kegiatan menghapal tetapi meliputi kegiatan panca indera peserta didik untuk mengenal, memahami, menganalisis dan mampu mengaktualisasikan fakta, fenomena atau informasi yang diterima, terutama informasi dari guru. peserta didik sebagai manusia merupakan makhluk berbudaya ia dapat diubah dan berubah (sikap dan perilaku) dengan pendidikan (Koentjaraningrat, 1994). Strategi pembelajaran berupa teknik elaborasi, teknik kompetisi, teknik kolaborasi, penugasan individu, peer group, FGD, kunjungan, dan sebagainya merupakan pendekatan strategi yang efektif dan produktif dalam penanaman dan pembinaan karakter peserta didik.

Sesuai sumber-sumber materi ajar peendidikan karakter atau pendidikan berintegritas selaras dengan kebijakan pemerintah (Depdikbud) yang mengintegrasikan materi pendidikan karakter kedalam berbagai mata pelajaran yang relevan baik ditingkat sekolah dasar maupun ditingkat sekolah lanjutan. Pendekatan-pendekatan yang bersifat inklusi dalam pendidikan karakter berperan menggali, membina, dan mengembangkan nilai-nilai karakter peserta didik dalam kehidupan keseharian mereka. Kemampuan guru dalam mendesain model, pola, strategi pembelajaran pendidikan karakter menjadi kunci dalam penerapan materi ajar atau topik-topik materi pendidikan karakter. Model-model pembelajaran seperti pembelajaran konsep (concept attainment model), model berfikir induktif, model inquiry training, model scientific inquiry, model penumbuhan kognitif, dan model-model pembelajaran kooperatif lainnya semuanya dapat menjadi pilihan sesuai situasi kondisi lapangan dan materi ajar yang akan disampaikan oleh para guru mata pelajaran. Singkatnya perancangan desain model dan evaluasi pembelajaran sangat diharapkan dari para guru pengampu mata pelajaran. di siamping itu yang tidak kalah pentingnya adalah kesiapan dan komitmen para guru dalam merekam hasil pembinaan dan pengembangan nilai-nilai karakter yang telah diberikan.

Evaluasi dan penilaian pendidikan karakter yang dapat direkam dan diselenggarakan setelah pembelajaran peserta didik dapat saja 
tertulis secara formal dan mungkin juga dalam bentuk tidak tertulis, evaluasi dan penilaian pendidikan karakter masih sangat situasional dan bervariasi, tetapi mutlak memerlukan rambu-rambu dan instrumen yang formal sesuai standar tingkatan pendidikan karakter yang ditugaskan dalam pendidikan karakter. Penilaian-penilaian program seperti : a) penilaian konteks; b) penilaian masukan/input; c) penilaian proses; d) penilaian keluaran/output. (Nana Sudjana, 1989) memerlukan instrumen. Instrumen evaluasi dan penilaian seyogianya di buat dengan memperhatikan berbagai syarat, kondisi, tujuan, subyek yang dinilai, dan isi penlaian yang diharapkan terukur, dsb.

Dipahami bahwa hasil akhir pada pembelajaran karakter terintegrasi oleh para pendidik adalah sangat tergantung dari besar kecilnya peubahan pola pikir, perubahan sikap dan perubahan perilaku yang bertanggung jawab, yang nampak dalam kehidupan keseharian peserta didik baik disekolah maupun dalam pergaulan di masyarakat lingkungannya dan seterusnya sampai mereka menjadi contoh generasi yang handal, unggul dan bertanggung jawab bagi pembengunan nasional Indonesia.

\section{METODE PENELITIAN}

Penelitian ini berada pada Sekolah Menengah Pertama Negeri (SMPN) di kabupaten Bulukumba yang merupakan lingkup lingkungan Dinas Pendidikan Kabupaten Bulukumba.

Fokus penelitian yang diukur adalah kemampuan guru mata pelajaran dalam mengidentifikasi dan merumuskan topik materi ajar pendidikan karakter, merumuskan tujuan dan indikator materi pendidikan karakter, penentuan sumber bahan ajar, pemmodelan dan teknik evaluasi hasil pembelajaran pendidikan karakter yang dilakukan oleh para guru mata pelajaran yan mengintegrasikan materi pendidikan karakter.

Penelitian ini menggunakan model/rancangan kualitatif Deskriptif yaitu menggambarkan dan mendiskripsikan data penelitian yang diperoleh kedalam bentuk elaborasi uraian. Teknik pengumpulan data yang digunakan adalah observasi yang ditujukan pada RPP dan rubrik pembelajaran guru yang di ikuti dengan lembar observasi untuk diisi oleh para guru mata pelajaran yang mengintegrasikan materi ajar pendidikan karakter, dan wawancara serta Focus Group Discussion (FGD) untuk mengukur penyamaan persepsi guru tentang materi pendidikan karakter antar kelompok bidang/mata pelajaran (PKn, Matematika, bahasa Indonesia, IPS, IPA, pendidikan agama Islam, dan seni budaya, yang seluruhnya berjumlah 50 orang selaku informan yang mewakili 19 SMPN). Teknik analisis data yang digunakan adalah statistik deskriptif yaitu dengan mereduksi ,menganalisis dan menafsir data faktual, yang dipadu dengan persentase dan tabulasi untuk kepentingan generalisasi data dari permasalahan penelitian ini.

\section{HASIL PENELITIAN}

\section{Kondisi Pelaksanaan Materi Ajar Pendidikan Karakter}

Materi ajar sebagai bahan pembelajaran guru di kelas merupakan bentuk dan wujud penguasaan kompetensi profesional guru mata pelajaran yang mengindikasikan kemampuan guru mata pelajaran dalam mempersiapkan isi pembelajarannya yang akan disajiakan dalam satu atau duakali pertemuan di kelas Materi ajar yang telah disusun dan dipersiapkan guru tentunya berbasis kompetensi inti/dasar (KI/KD) yang disususn dengan berbagai pertimbamgan dan persyaratan minimal 
Data yang diperoleh dari para guru SMPN yang berjumlah 50 orang sebagai informan penelitian ini, dapat dideskripsikan dan digambarkan tentang bagaimana intensitas pembelajaran materi pendidikan karakter dalam setiap pembahasan pembelajaran di kelas serta dimana mengacu dalam merancang materi pendidikan karakter terintegrasi dalam mata pelajaran yang mereka ampuh. Hal tersebut dapat dikemukakan hasil analisis data, seperti dalam tabel berikut:

Tabel 5.1. Keadaan Intensitas Pembelajaran Materi Pendidikan Karakter Terintegrasi oleh Para Guru MP (Informan)

\begin{tabular}{llcccc}
\hline No. & \multicolumn{1}{c}{$\begin{array}{c}\text { Mata Pelajaran } \\
\text { Terintegrasi }\end{array}$} & $\begin{array}{c}\text { Selalu } \\
(\mathbf{\%})\end{array}$ & $\begin{array}{c}\text { Sering } \\
(\mathbf{\%})\end{array}$ & $\begin{array}{c}\text { Jarang } \\
(\boldsymbol{\%})\end{array}$ & $\begin{array}{c}\text { Tidak } \\
\text { pernah } \\
(\boldsymbol{\%})\end{array}$ \\
\hline 1 & Mata Pelajaran PKn & 84,62 & 15,38 & 0 & 0 \\
\hline 2 & Mata Pelajaran Matematika & 25 & 62,5 & 12,5 & 0 \\
\hline 3 & Mata Pelajaran IPA & 57,14 & 14,29 & 28,57 & 0 \\
\hline 4 & Mata Pelajaran IPS & 33,33 & 66,67 & 0 & 0 \\
\hline 5 & $\begin{array}{l}\text { Mata Pelajaran Bhs. } \\
\text { Indonesia }\end{array}$ & 33,33 & 55,56 & 11,11 & 0 \\
\hline 6 & Mata Pelajaran PAI & 85,71 & 14,29 & 0 & 0 \\
\hline
\end{tabular}

Sumber: Hasil Analisis Angket

Berdasarkan data dalam tabel 5.1 di atas dapat dikemukakan bahwa para guru mata pelajaran yang mengintegrasikan materi pendidikan karakter cukup padat (intensitas) dalam pengintegrasian materi pendidikan karakter kedalam bahan ajar materi mata pelajaran pokok. Data di atas menunjukkan bahwa para guru mata pelajaran PKn dan guru mata pelajaran PAI yang menunjukkan intensitas tinggi yaitu para guru setiap pembelajaran di kelas selalu meyampaikan/mengintegrasikan materi pendidikan karakter.

Dipahami bahwa mata pelajaran PKn dan mata pelajaran PAI sangat dekat dan bahkan boleh dikatakan tidak terpisahkan dari materi pendidikan karakter namun para guru mata pelajaran PKn dan mata palajaran PAI selalu menempatkan pendidikan karakter kedalam kajian standar yang ditetapkan (18 butir materi pendidikan karakter), terutama tentang kajian nilai-nilai religius, kejujuran, kedisiplinan dan tanggung jawab.

Menurut penuturan Achmad, R, selaku kepala SMPN 3 Bulukumba, bahwa "pembelajaran pendidikan karakter di sekolah membutuhkan dukungan yang kuat dan saling konfirmasi antar komponen sekolah yang sekaligus dapat menjadi contoh dan suritauladan bagi peserta didik sebagai warga binaan di sekolah."

Data di atas menunjukkan bahawa para guru mata pelajaran (informan penelitian) memiliki kemampuan mengkaji, meganalisis dan menempatkan materi ajar pendidikan karakter yang terintegrasi kedalam berbagai macam mata pelajaran di tingkat SMPN.

Materi ajar menjadi penting dipersiapkan oleh guru sebelum masuk kelas karena materi ajar akan menjauhkan guru mata pelajaran dari kesan bahwa seorang guru yang siap mengajar dengan bahan ajar yang disusun selengkapnya adalah guru yang kurang memiliki kompetensi profesional, yang tidak 
sekedar hanya memegang buku paket atau buku kepustakaan, lalu melalukan pembelajaran dengan instruksi-instruksi pembelajarannya kepada peserta didik di kelas.

Dari data hasil penelitian informan guru mata pelajaran yang diperoleh dapat dikemukakan kurang lebih $92 \%$ guru mata pelajaran telah mengetahui mata pelajaran pendidikan karakter materi ajar terstandar terintegrasi dalam berbagai mata pelajaran di SMPN. Sebaran gambaran kondisi pengembangan materi pendidikan karakter terintegrasi dalam mata pelajaran (yang dikembangkan guru) dalam kelas dapat dikemukakan sesuai dengan topik inti/ KD yang dibahas (selalu) oleh para guru di SMPN, sebagaimana dalam tabel 5.4 berikut.

Tabel 5.2 Konsep/Topik Inti Materi Ajar Pendidikan Karakter Terintegrasi Yang (selalu) Dikembangkan Guru MP (Informan)

\begin{tabular}{|c|c|c|}
\hline No. & $\begin{array}{l}\text { Topik/ Konsep Isi yang } \\
\text { Dikembangkan }\end{array}$ & $\begin{array}{c}\text { Terintegrasi dalam Materi/ KD Mata } \\
\text { Pelajaran }\end{array}$ \\
\hline 1. & Religius & PAI, PKn dan IPS \\
\hline 2. & Jujur/Kejujuran & $\begin{array}{l}\text { PAI, PKn, IPA, IPS, Bhs. Indonesia dan } \\
\text { Matematika }\end{array}$ \\
\hline 3. & Toleransi & PAI, PKn, IPS, Bhs. Indonesia dan IPA \\
\hline 4. & Disiplin & $\begin{array}{l}\text { PAI, PKn, IPA, IPS, Bhs. Indonesia,dan } \\
\text { Matematika }\end{array}$ \\
\hline 5. & Kerja Keras & $\begin{array}{l}\text { PAI, PKn, IPA, IPS, Bhs. Indonesia dan } \\
\text { Matematika }\end{array}$ \\
\hline 6. & Kreatif & $\begin{array}{l}\text { PAI, PKn, IPA, IPS, Bhs. Indonesia dan } \\
\text { Matematika }\end{array}$ \\
\hline 7. & Mandiri & $\begin{array}{l}\text { PAI, PKn, IPA, IPS, Bhs. Indonesia dan } \\
\text { Matematika }\end{array}$ \\
\hline 8. & Rasa Ingin Tahu & $\begin{array}{l}\text { PAI, PKn, IPA, IPS, Bhs. Indonesia dan } \\
\text { Matematika }\end{array}$ \\
\hline 9. & Demokratis & PKn, PAI dan IPS \\
\hline 10. & Semangat Kebangsaan & PKn, PAI, IPS dan Bhs. Indonesia \\
\hline 11. & Cinta Tanah Air & $\begin{array}{l}\text { PAI, PKn, IPA, IPS, Bhs. Indonesia dan } \\
\text { Matematika }\end{array}$ \\
\hline 12. & Menghargai Prestasi & $\begin{array}{l}\text { PAI, PKn, IPA, IPS, Bhs. Indonesia dan } \\
\text { Matematika }\end{array}$ \\
\hline 13. & $\begin{array}{l}\text { Bersahabat/ } \\
\text { Berkomunikasi }\end{array}$ & Bhs. Indonesia, PAI, PKn, IPS dan IPA \\
\hline 14. & Cinta Damai & $\begin{array}{l}\text { PAI, PKn, IPA, IPS, Bhs. Indonesia dan } \\
\text { Matematika }\end{array}$ \\
\hline 15. & Gemar Membaca & Bhs. Indonesia, PAI dan PKn \\
\hline 16. & Peduli Lingkungan & $\begin{array}{l}\text { PAI, PKn, IPA, IPS, Bhs. Indonesia dan } \\
\text { Matematika }\end{array}$ \\
\hline 17. & Peduli Sosial & $\begin{array}{l}\text { PAI, PKn, IPA, IPS, Bhs. Indonesia dan } \\
\text { Matematika }\end{array}$ \\
\hline 18. & Tanggung Jawab & $\begin{array}{l}\text { PAI, PKn, IPA, IPS, Bhs. Indonesia dan } \\
\text { Matematika }\end{array}$ \\
\hline
\end{tabular}

Sumber: Hasil Analisis Angket 
Gambaran data dalam tabel 5.2 di atas menunjukkan bahawa para guru mata pelajaran terintegrasi materi pendidikan karakter mengetahui dan memahami isi materi pendidikan karakter yang seharusnya diintegrasikan dalam pokok bahasan/ topik inti dari materi ajar bidang studi/ mata pelajaran yang akan dibahas dalam pertemuan di kelas.

\section{Tingkat kemampuan (ability) guru dalam penguasaan materi ajar, pemilihan sumber, metode, model, dan evaluasi serta penilaian dalam pembelajaran pendidikan karakter terintegrasi pada SMPN}

\section{Kemapuan (ability) guru tentang isi pendidikan karakter}

Kemampuan guru mengenai pengetahuan dan pemahaman tentang pendidikan karakter, sebagaimana dikemukakan di atas, menunjukkan bahwa para guru mata pelajaran terintegrasi materi pendidikan karakter telah memahami tentang tema, konsep dan topik-topik inti yang harus diintegrasikan dalam materi mata pelajaran induknya (materi yang relevan). Dengan kata lain bahwa para guru telah memahami materi ajar apa dan yang mana yang seharusnya disajikan di kelas.

Dari data yang diperoleh ditemukan bahwa sekitar $75 \%$ informan guru telah melakukan inovasi dan berkreasi untuk lebih memperdalam pehaman para peserta didik dari apa yang dibahas (dipelajari) dengan menambahkan materi pendidikan karakter dengan mengangkat cerita-cerita rakyat setempat dan yang populer di masyarakat. Cara ini menurut mereka dapat membuat peserta didik lebih menghayati materi ajar pendidikan karakter yang sedang disajikan di kelas.

Berikut dikemukakan data kemampuan guru memahami pedoman dan menandai adanya pendidikan karakter terintegrasi, seperti dalam tabel 5.5 berikut:

Tabel 5.5 Pedoman Guru MP (Informan) dalam Menandai Materi Pendidikan Karakter

\begin{tabular}{llccccc}
\hline \multirow{2}{*}{ No. } & \multirow{2}{*}{$\begin{array}{c}\text { Mata Pelajaran } \\
\text { Terintegrasi }\end{array}$} & Kurikulum & Silabus/SAP & SK/KD & $\begin{array}{c}\text { Tujuan/ } \\
\text { Indikator }\end{array}$ & Lainnya \\
\cline { 3 - 6 } & & $15,39 \%$ & $53,85 \%$ & $7,69 \%$ & $23,08 \%$ & 0 \\
\hline 1 & $\begin{array}{l}\text { Mata Pelajaran } \\
\text { PKn }\end{array}$ & $25 \%$ & $50 \%$ & $37,5 \%$ & $12,5 \%$ & 0 \\
\hline 2 & $\begin{array}{l}\text { Mata Pelajaran } \\
\text { Matematika }\end{array}$ & & & & & \\
\hline 3 & Mata Pelajaran IPA & $42,86 \%$ & $14,29 \%$ & $14,29 \%$ & $28,57 \%$ & 0 \\
\hline 4 & Mata Pelajaran IPS & 0 & 0 & $33,33 \%$ & $66,67 \%$ & 0 \\
\hline 5 & $\begin{array}{l}\text { Mata Pelajaran } \\
\text { Bhs. Indonesia }\end{array}$ & $33,33 \%$ & $11,11 \%$ & $22,22 \%$ & $55,56 \%$ & 0 \\
\hline 6 & Mata Pelajaran PAI & $28,57 \%$ & $28,57 \%$ & $14,29 \%$ & $28,57 \%$ & 0 \\
\hline
\end{tabular}

Sumber : Analisis data angket

Dari data di atas menunjukka bahwa para guru mata pelajaran dalam mengintegrasikan materi pendidikan karakter, ternyata pendoman dalam menandai materi sangat bervariasi/ berbeda pandangan, dari data di atas menunjukkan bahwa sebagian besar guru telah menandai adanya materi pendidikan karakter sejak merumuskan tujuan dan menetapkan indikator pembelajaran dari materi ajar mata pelajarannya.

Muhammad Yusuf, salah seorang guru MP PKn di SMPN 3 Bulukumba, menuturkan bahwa "Sajian bahan ajar 
materi pendidikan karakter yang terintegrasi, sebaiknya benar-benar dirancang/disusun tersendiri yang berbasis pada topik/kompetensi inti/ dasar menurut isi program semester dan dilaksanakan secara konsekuen".
Apakah guru merumuskan tersendiri tujuan khusus dan indikator teretentu khusus untuk materi pendidikan karakter terintegrasi. Pertanyaan ini akan dijawab pada uraian dalam tabel 5.6 berikut:

Tabel 5.6 Dalam RPP guru mencantumkan rumusan secara khusus tujuan dan indikator pembelajaran materi pendidikan karakter

\begin{tabular}{llcccc}
\hline \multirow{2}{*}{ No. } & Mata Pelajaran Terintegrasi & \multicolumn{4}{c}{$\begin{array}{c}\text { Intensitas Perumusan Tujuan Khusus } \\
\text { Materi Terintegrasi }\end{array}$} \\
\cline { 3 - 6 } & & Selalu & Sering & Jarang & $\begin{array}{c}\text { Tidak } \\
\text { pernah }\end{array}$ \\
\hline 1 & Mata Pelajaran PKn & $76,92 \%$ & $15,39 \%$ & 0 & $7,69 \%$ \\
\hline 2 & Mata Pelajaran Matematika & $12,5 \%$ & $62,5 \%$ & $12,5 \%$ & $12,5 \%$ \\
\hline 3 & Mata Pelajaran IPA & $28,57 \%$ & $42,86 \%$ & $28,57 \%$ & 0 \\
\hline 4 & Mata Pelajaran IPS & $16,67 \%$ & $50,0 \%$ & $33,33 \%$ & 0 \\
\hline 5 & Mata Pelajaran Bhs. & $33,33 \%$ & $22,22 \%$ & $44,44 \%$ & 0 \\
& Indonesia & & & & 0 \\
\hline 6 & Mata Pelajaran PAI & $85,71 \%$ & $14,29 \%$ & 0 & 0 \\
\hline
\end{tabular}

Sumber : Analisis data angket

Berdasarkan data pada tabel 5.6 di atas ternyata sebagian besar guru mata pelajaran yang mengintegrasikan materi pendidikan karakter pada saat menyusun RPP telah melakukan perumusan indikator dan tujuan pembelajaran materi pendidikan karakter secara khusus atau butir tersendiri (terpisah dari rumusan tujuan materi pokok mata pelajaran induk). Tentu data ini menggembirakan, karena para guru (informan penelitian) telah melakukan proses pengintegrasian materi pendidikan karakter secara sistematik dan utuh dalam penyajian materi pendidikan karakter terintegrasi di kelas.

\section{Pemilihan Sumber Bahan Ajar Materi Pendidikan Karakter}

Dipahami bahwa sumber bahan ajar yang dipilih guru sangat menentukan kualitas materi dan isi pembelajaran yang akan disajikan guru di kelas. Disamping itu pemilihan sumber bahan ajar yang tepat dan sesuai dengan standar yang ditentukan, terutama relevansi materi topik inti atau kompetensi dasar yang akan dibahas sebagai bahan pmbelajaran di kelas.

Berdasarkan data penelitian ini, dapat dikemukakan informasi tentang sumber-sumber bahan ajar yang dipilih dan ditetapkan guru dalam rangka megintegrasikan materi pendidikan karakter pada SMPN di Bulukumba. Gambaran data/informasi tentang sumber bahan ajar dapat dikemukakan sebagaimana dalam tabel 5.5 berikut: 
Tabel 5.5 Keadaan pemilihan/Penetuan Sumber Bahan Ajar oleh Para Guru MP (Informan)

\begin{tabular}{llcccc}
\hline \multirow{2}{*}{ No. } & Mata Pelajaran Terintegrasi & \multicolumn{4}{c}{ Frekuensi/intensitas Pencarian Sumber } \\
& & Sahan Ajar \\
\cline { 3 - 6 } & & Selalu & Sering & Jarang & $\begin{array}{c}\text { Tidak } \\
\text { Pernah }\end{array}$ \\
\hline 1. & Mata Pelajaran PKn & $7,69 \%$ & $84,62 \%$ & $7,69 \%$ & 0 \\
\hline 2. & Mata Pelajaran Matematika & $12,5 \%$ & $62,5 \%$ & $12,5 \%$ & $12,5 \%$ \\
\hline 3. & Mata Pelajaran IPA & $71,43 \%$ & $28,57 \%$ & 0 & 0 \\
\hline 4. & Mata Pelajaran IPS & $16,67 \%$ & $50 \%$ & $33,33 \%$ & 0 \\
\hline 5. & Mata Pelajaran Bhs. & $11,11 \%$ & $77,78 \%$ & $11,11 \%$ & 0 \\
\hline & Indonesia & & & & 0 \\
\hline 6. & Mata Pelajaran PAI & 0 & $100 \%$ & 0 & 0 \\
\hline
\end{tabular}

Sumber : Analisis data angket

Berdasarkan data di atas dari 50 orang informan guru, sebagian besar guru (lebih dari 95\%) telah berusaha mencari sumber-sumber materi pembelajaran pendidikan karakter yang akan diintegrasikan kedalam materi pokok mata pelajaran yang akan disajikan di kelas.

Lebih lanjut dikemukakan tentang temuan data penelitian mengenai macam

kitab, buku dan media pembelajaran yang di upayakan guru sebagai sumber-sumber tambahan dalam melengkapi materi ajar pendidikan karakter yang akan diintegrasikan. Dalam tabel berikut dikemukakan tentang macam sumber yang dipilih guru mata pelajaran (informan guru SMPN), sebagai berikut:

Tabel 5.6 Macam-macam Sumber Bahan Ajar Materi Pendidikan Karakter yang Digunakan Guru MP (Informan)

\begin{tabular}{clcccc}
\hline No & \multicolumn{1}{c}{ Bahan Sumber Ajar } & Selalu & Sering & $\begin{array}{c}\text { Kadang- } \\
\text { kadang }\end{array}$ & $\begin{array}{c}\text { Tidak } \\
\text { Pernah }\end{array}$ \\
\hline 1. & Bacaan dari kitab suci Al- & $32 \%$ & $42 \%$ & $20 \%$ & $2 \%$ \\
& Qur'an & $16 \%$ & $28 \%$ & $34 \%$ & $8 \%$ \\
\hline 2. & Bacaan dari al hadist & $22 \%$ & $28 \%$ & $38 \%$ & $2 \%$ \\
\hline 3. & Buku terbit resmi & $4 \%$ & $14 \%$ & $46 \%$ & $16 \%$ \\
\hline 4. & Buku fiksi ilmiah & $4 \%$ & $10 \%$ & $40 \%$ & $14 \%$ \\
\hline 5. & Buku fiksi non ilmiah & $10 \%$ & $34 \%$ & $32 \%$ & $6 \%$ \\
\hline 6. & Biografi tokoh & $20 \%$ & $44 \%$ & $24 \%$ & $4 \%$ \\
\hline 7. & Nilai-nilai kearifan lokal & $30 \%$ & $44 \%$ & $8 \%$ & $2 \%$ \\
\hline 8. & Fenomena perilaku peserta & & & & \\
\hline didik & Hasil pengalaman guru & $22 \%$ & $42 \%$ & $14 \%$ & 0 \\
\hline 10. & Cerita rakyat/dongeng & $2 \%$ & $26 \%$ & $42 \%$ & $10 \%$ \\
\hline 11. & Media cetak & $16 \%$ & $42 \%$ & $26 \%$ & $2 \%$ \\
\hline 12. & Media audio visual & $12 \%$ & $28 \%$ & $38 \%$ & $8 \%$ \\
\hline 13. & Lainnya ... & 0 & 0 & $4 \%$ & $6 \%$ \\
\hline
\end{tabular}

Sumber : Analisis data angket

Catatan : (beberapa respon tidak mengisi lengkap isian tabel 5.9) 
Berdasarkan tabel 5.6 di atas menginformasikan bahwa para guru mata pelajaran telah berupaya memahami dan mencari sumber-sumber bahan ajar materi pendidikan karakter terintegrasi guna menjamin terciptanya materi ajar pendidikan karakter yang memenuhi standar, bermutu dan menarik serta produtif bagi peserta didik. Para guru mata pelajaran yang mengintegrasikan materi pendidikan karakter telah memahami betapa luas, dalam dan berdimensi materi pendidikan karakter yang harus dipikirkan guru mata pelajaran dalam rangka mendesain materi ajar pendidikan karakter terintegrasi.

\section{Pemilihan Metode pembelajaran Materi Pendidikan Karakter Terintegrasi}

Berdasarkan data yang diperoleh, berikut dikemukakan berbagai cara/ metode yang ditempuh para guru mata pelajaran yang mengintegrasikan materi pendidikan karakter pada SMPN Kabupaten Bulukumba. Metode pembelajaran dipahami bahwa yang dipilih dan ditetapkan guru sebagai cara penyampaian materi pembelajaran sangat penting, karena menentukan langkahlangkah (skenario) pembelajaran dan bahkan dapat menentukan baerhasil tidaknya tujuan pembelajaran yang telah ditetapkan dalam RPP guru MP. Berikut dikemukakan gambaran tentang penggunaan metode pembelajaran materi ajar materi pendidikan karakter, seperti pada tabel 5.7 berikut:

Tabel 5.7 Ragam Metode Pembelajaran Materi Pendidikan Karakter Terintegrasi Yang Digunakan Guru MP (Informan)

\begin{tabular}{ccccccc}
\hline & & \multicolumn{4}{c}{ Metode pembelajaran Pendidikan Karakter } \\
\cline { 3 - 6 } No. & $\begin{array}{c}\text { Mata Pelajaran } \\
\text { Terintgrasi }\end{array}$ & Ceramah & Diskusi & $\begin{array}{c}\text { Tugas } \\
\text { Individu }\end{array}$ & $\begin{array}{c}\text { Tugas } \\
\text { Kelompok }\end{array}$ & $\begin{array}{c}\text { Kujungan/ } \\
\text { Praktek }\end{array}$ \\
\hline 1. & $\begin{array}{c}\text { Mata Pelajaran } \\
\text { PKn }\end{array}$ & 0 & $23,08 \%$ & 0 & $69,23 \%$ & $23,08 \%$ \\
\hline 2. & $\begin{array}{c}\text { Mata Pelajaran } \\
\text { PAI }\end{array}$ & $42,86 \%$ & $28,57 \%$ & 0 & 42,86 & $14,29 \%$ \\
\hline 3. & $\begin{array}{c}\text { Mata Pelajaran } \\
\text { IPA }\end{array}$ & 0 & $14,29 \%$ & 0 & $71,43 \%$ & $14,29 \%$ \\
\hline 4. & $\begin{array}{c}\text { Mata Pelajaran } \\
\text { IPS }\end{array}$ & 0 & $33,33 \%$ & $16,67 \%$ & $83,33 \%$ & $16,67 \%$ \\
\hline 5. & $\begin{array}{c}\text { Mata Pelajaran } \\
\text { Bhs. Indonesia }\end{array}$ & 0 & $66,67 \%$ & $11,11 \%$ & $33,33 \%$ & $33,33 \%$ \\
\hline 6. & $\begin{array}{c}\text { Mata Pelajaran } \\
\text { Matematika }\end{array}$ & $12,5 \%$ & $50 \%$ & $37,5 \%$ & $87,5 \%$ & $25 \%$ \\
\hline
\end{tabular}

Sumber: Analisis data angket

Catatan: Beberapa responden menceklis semua kemungkinan jawaban yang disiapkan

Data dari tabel 5.7 di atas menunjukkan bahwa para guru mata pelajaran yang mengintegrasikan materi ajar pendidikan karakter telah menempuh cara pembelajaran yang variatif dan kombinatif, yang secara rerata berada pada metode diskusi dan metode tugas kelompok. Walaupun bagi para guru mata pelajaran PAI masih ada sebagian lebih banyak menggunaka metode ceramah dalam penyajian pembelajarannya di kelas. 
Pemilihan Model pembelajaran Materi Pendidikan Karakter Terintegrasi

Sesuai data yang diperoleh, dapat dikemukakan bagaimana para guru mata pelajaran memilih dan menetukan model pembelajaran dalam menyampaikan materi ajar pendidikan karakter. Berikut dikemukakan gambaran data tentang penentuan/pemilihan model-model pembelajaran oleh para guru mata pelajaran, seperti dalam tabel 5.10 berikut:

Tabel 5.8 Model Pembelajaran Pendidikan Karakter yang Digunakan Guru MP (Informan)

\begin{tabular}{clcccc}
\hline No. & \multicolumn{1}{c}{ Model Pembelajaran } & Selalu & Sering & $\begin{array}{c}\text { Kadang- } \\
\text { kadang }\end{array}$ & $\begin{array}{c}\text { Tidak } \\
\text { pernah }\end{array}$ \\
\hline 1. & Bermain Peran & $12 \%$ & $48 \%$ & $28 \%$ & $8 \%$ \\
\hline 2. & Simulasi & $6 \%$ & $50 \%$ & $30 \%$ & $6 \%$ \\
\hline 3. & $\begin{array}{l}\text { Teknik Mengklarifikasi nilai } \\
\text { (Inquiry) }\end{array}$ & $12 \%$ & $42 \%$ & $22 \%$ & $6 \%$ \\
\hline 4. & Problem Solving & $12 \%$ & $44 \%$ & $22 \%$ & $8 \%$ \\
\hline 5. & Focus Group Discussion (FGD) & $12 \%$ & $40 \%$ & $28 \%$ & $8 \%$ \\
\hline
\end{tabular}

Sumber : Analisis data angket

Data dalam tabel 5.8 di atas mengggambarkan bahwa para guru mata pelajaran yang mengintegrasikan pendidikan karakter menggunakan model-model pembeelajaran yang variatif juga, sekalipun terbukti bahwa salah satu model pembelajaran tidak selalu digunakan, tetapi ada model-model tertentu yang lebih sering digunakan dalam pembelajaran dihadapan peserta didik. Data dalam tabel di atas juga menunjukkan bahwa ada sebagian guru mata pelajaran yang sama sekali belum pernah menguji coba model-model pembelajaran tertentu dalam upaya penyajian materi ajarnya dihadapan peserta didik.

\section{Pemilihan dan Penggunaan Media Materi Pendidikan Karakter}

Berdasarkan data yang diperoleh dapat dikemukakan tentang bagaimana para guru mata pelajaran yang mengintegrasikan materi pendidikan karakter berupaya secara inovatif dan kreatif memilih dan menggunakan media pembelajaran yang bisa membantu dan memancing kegairahan belajar para peserta didik tentu berdasarkan pertimbangan dan disesuaikan dengan kebutuhan materi ajar pendidikan karakter terintegrasi. Kedaan penggunaan media oleh para guru dapat dilihat pada tabel 5.9 berikut:

Tabel 5.9 Keadaan Pemilihan/Penggunaan Media Pembelajaran Pendidikan Karakter Terintegrasi oleh Para Guru MP (Informan)

\begin{tabular}{clcccc}
\hline No. & \multicolumn{1}{c}{ Media Pembelajaran } & Selalu & Sering & $\begin{array}{c}\text { Kadang- } \\
\text { kadang }\end{array}$ & $\begin{array}{c}\text { Tidak } \\
\text { pernah }\end{array}$ \\
\hline 1. & Foto/Gambar & $24 \%$ & $50 \%$ & $20 \%$ & $4 \%$ \\
\hline 2. & $\begin{array}{l}\text { Tulisan Power Point yang } \\
\text { Ditayangkan }\end{array}$ & $10 \%$ & $34 \%$ & $28 \%$ & $10 \%$ \\
\hline 3. & Video Clip & $8 \%$ & $14 \%$ & $34 \%$ & $22 \%$ \\
\hline 4. & Peragaan dari Peserta Didik & $14 \%$ & $44 \%$ & $26 \%$ & $4 \%$ \\
\hline 5. & Film & $6 \%$ & $14 \%$ & $26 \%$ & $24 \%$ \\
\hline
\end{tabular}

Sumber : Analisis data angket nomor 29, Agustus 2017 
Berdasarkan 5.9 di atas ternyata para guru mata pelajaran yang mengintegrasikan materi ajar pendidikan karakter telah cukup inovatif dan kreatif dalam memilih dan menggunakan media pembelajaran sebagai alat bantu dalam penyajian materi ajarnya di depan para peserta didik. Dalam tabel di atas terlihat pula sebagia guru mata pelajaran ada yang belum pernah mencoba menggunakan media-media pembelajaran tertentu.

\section{Evaluasi dan Penilaian Pendidikan Karakter}

Sebagaimna dipahami bahwa evaluasi dan penilaian hasil pembelajaran pendidikan karakter oleh para guru mata pelajaran yang mengintegrasikan materi ajar pendidikan karakter sangatlah variatif, dalam arti para guru mata pelajaran menilai hasil belajar para peserta didik dengan tenik dan metode yang berbeda. Penilaian hasil belajar peserta didik atas prestasi atau hasil belajar pendidikan karakter dapat dilakukan secara tertulis ataupun dengan tidak tertulis.

Nilai hasil belajar peserta didik dalam hal pendidikan karakter dapat direkam oleh guru dan dicatat dalam rapor dan dapat juga dilakukan melalui penampilan, sikap perilaku dan tindak tanduk para peserta didik dalam pergaulan kesehariannya di lingkungan sekolah maupun di luar lingkungan sekolah. Bagi guru yang merekam nilai hasil belajar peserta didik dalam hal pendidikan karakter, dapat saja terintegrasi dalam arti bahwa para peserta didik yang dinilai dalam satu hasil belajar mata pelajaran, sudah terintegrasi sekaligus nilai pendidikan karakternya, dan mungkin juga guru merekam nilai pendidikan karakter melalui catatan dalam rapor dengan mendeskripsikan secara kualitatif untuk setiap dokumen rapor peserta didik, sehingga peserta didik dapat mengetahui hasil belajar atau nilai hasil belajar tentang karakter yang dimiliki.

\section{PEMBAHASAN}

Dalam hal kemampuan (ability) para guru (informan) pada SMPN di kabupaten Bulukumba yang mengintegrasikan materi ajar pendidikan karakter dalam mengembangkan materi ajar pendidikan karakter, menunjukkan adanya kemampuan yang memadai untuk menyimak, mengkaji dan menganalisis serta menentukan transformasi dari 18 topik materi standar pendidikan karakter terintegrasi sesuai subtansi materi dalam kompetensi dasar/topik inti yang akan dikembangkan menjadi materi ajar berbasis materi pelajaran yang diampu masing-masing guru.

Di samping itu, para guru mata pelajaran yang mmengintegrasikan materi pendidikan karakter telah memahami pentingnya peran nilai-nilai kearifan lokal dan melakukan lintas literasi dalam melangkapi dan memperdalam materi ajar pendidikan karaker yang akan diintegrasikan kedalam materi pokok mata pelajaran induk yang diampu.

Upaya guru mata pelajaran yang mengintegrasikan materi pendidika karakter, dalam mendesain materi ajar pendidikan karakter belum maksimal dalam hal teknis penguasaan epistimologis pembelajaran pendidikan karakter, terutama tentang strategi pemilihan model pembelajaran, pemilihan dan penggunaan media belajar, penggunaan dan penentuan alat bantu serta pemilihan sumber-sumber bahan ajar pendidikan karakter. Akibat dari halhal tersebut para guru mata pelajaran nampaknya masih kesulitan dalam membangkitkan dan menumbuhkembangkan pola pikir, sikap, dan perilaku reflektif peserta didik atas 
nilai-nilai pendidikan karakter yang lebih produktif.

Penguatan pendidikan karakter ditingkat SMPN melalui implementor guru masih memerlukan pendidikan dan latihan khusus untuk memperkuat para guru mata pelajaran yang mengintegrasikan materi ajar pendidikan karakter sisi-sisi kelemahan metoda saintifik (scientific) yang berbasis K13, sehingga antara upaya guru dan kegiatan/hasil belajar pendidikan karakter peserta didik menunjukkan hasil yang terus meningkat dalam hal-hal penghayatan dan pengamalan nilai-nilai sosial, religius, etik, dan moral serta tanggung jawab peserta didik yang lebih nyata dalam kehiduan sehari-hari mereka.

Peraturan menteri pendidikan dan kebudayaan nomor 24 tahun 2016 tentang kompetensi inti dan kompetensi dasar, menekankan metoda pendekatan berbasis kurikulum 13 yang selama ini oleh para guru menjadi acuan dalam pembelajaran mereka, nampaknya masih perlu para guru mata pelajaran untuk mengembangkan inovasi dan kreasi tentang metode pembelajaran yang bersifat reflektif, introspeksi dan pencarian nilai-nilai esensial dari peserta didik, dalam arti bahwa peserta didik dibelajarkan untuk menemukan esensi nilai-nilai internal mereka.

\section{PENUTUP}

Berdasarkan hasil analisis dan pembahasan hasil penelitian dari permasalahan yang dikaji dalam penelitian ini, maka dapat ditarik kesimpulan sebagai berikut: (1) Bahwa kemampuan (ability) para guru (informan) pada SMPN di kabupaten Bulukumba yang mengintegrasikan materi ajar pendidikan karakter dalam mengembangkan materi ajar menunjukkan; (a) adanya kemampuan yang memadai untuk menyimak, mengkaji dan menganalisis serta menentukan transformasi 18 topik materi standar pendidikan karakter terintegrasi sesuai subtansi materi dalam kompetensi dasar/topik inti yang akan dikembangkan menjadi materi ajar berbasis materi pelajaran yang diampu, dan (b). Sebagian besar guru mata pelajaran yang mengintegrasikan materi ajar pendidikan karakter telah memahami pentingnya peran nilai-nilai kearifan lokal dan melakukan lintas literasi dalam melangkapi dan memperdalam materi ajar pendidikan karaker yang akan diintegrasikan kedalam materi pokok mata pelajaran induk yang diampu. (2) Bahwa (a) Tingkat kemampuan (ability) penguasaan materi ajar pendidikan karakter oleh guru mata pelajaran yang mengintegrasikan materi ajar pendidikan karakter tergolong tinggi, dan (b) Secara teknis oprasional (implementasi) pembelajaran kemampuan para guru MP masih menemui kesulitan dalam hal-hal spesifikasi oprasional (penentuan indikator dan tujuan pembelajaran secara khusus isi materi ajar pendidikan karakter), penetapan strategi metode, pemodelan dan penyiapan media pembelajaran yang tepat, penyiapan waktu khusus serta evaluasi dan penilaian hasil pembelajaran pendidikan karakter secara utuh dan sistematis sebagai sebuah desain dan pola pengintegrasian materi ajar pendidikan karakter yang baik.

Berdasarkan kesimpulan hasil penelitian ini maka disarankan: (1) Kepada Kepala Dinas Dikbud, seyogianya dibuatkan regurasi tentang penguatan pembelajaran pendidikan karakter yang terpogram lebih baik, khususnya untuk para guru SMPN di Kabupaten Bulukumba dan sekiranya memungkinkan dilakukan pendidikan dan latihan tentang pendidikan karakter terintegrasi. (2) Kepada para Kepala SMPN di Kabupaten Bulukumba, 
seyogianya diusulkan/dibuatkan pola desain pembelajaan pendidikan karakter terintegrasi yang lebih sistematis, utuh dan terprogram baik berbasis mata pelajaran induk (tertentu) dan apabila diperlukan materi pendidikan karakter dijadikan mata pelajaran muatan lokal disamping itu perlu membuat program untuk pelatihan terbatas untuk mata pelajaran serumpun atau sejenis tentang materi pembelajaran pendidikan karakter agar diperolah model pengintegrasian materi ajar pendidikan karakter tyang lebih baik (3) Untuk para Guru SMPN di Kabupaten Bulukumba, agar membentuk kelompok-kelompok mata pelajaran sejenis atau serumpun untuk membahas dan mendiskusikan pola desain pembelajaran materi ajar pendidikan karakter yang lebih sistematis, utuh terprogram dan produktif

\section{DAFTAR PUSTAKA}

Adam Kuper \& Jessica Kuper, 2008. Alih bahasa Munandar Haris, dkk. Ensiklopedi Ilmu-ilmu Sosial. Jakarta: PT. Raja Grafindo Persada

Darmanto. JT \& Sudakto, PH. 1986. Mencari Konsep Manusia Indonesia. Jakarta: Erlangga.

Departemen Pendidikan dan Kebudayaan. 1998. UUD 45, P4, GBHN dan Kewaspadaan Nasional (Bahan Penataran). Jakarta: Dirjen Dikti

Dirjen Dikdasmen, 2005. Materi Latihan Terintegrasi Pendidikan Kewarganegaraan. Jakarta : Dirjen Dikti Bagian I

Koentjaraningrat. 1994. Kebudayaan Mentalitas dan Pembangunan. Jakarta: PT. Gramedia Pustaka Utama

Lickona, Thomas. 2012. Character Matters. Jakarta: Bumi Aksara
Moleong, Lexy J. 1989. Metodologi Penelitian Kualitatif. Bandung : Remadja Karya.

Mustari, Muhammad. 2014. Nilai Karakter. Jakarta: PT Rajagrafindo Persada.

Pusat Pembinaan dan Pengembangan Bahasa. 1975. Pedoman Umum Ejaan Bahasa Indonesia yang Disempurnakan. Jakarta : Departemen Pendidikan dan Kebudayaan Republik Indonesia.

Prawiroatmodjo Dendosurono. dkk, 1984. Pendidikan

Kependudukan dan Lingkungan Hidup Suatu Pengantar. Jakarta : IKIP Jakarta

Saleh, Muwafik AKH. 2012. Membangun Karakter dengan Hati Nurani. Jakarta: Erlangga.

Saptono. 2011. Dimensi-dimensi Pendidikan Karakter (wawasan, strategi dan langkah-langkah praktis). Jakarta: Erlangga.

Sudjana, Nana. 1989. Pembinaan dan Pengembangan Kurikulum di Sekolah. Bandung: Sinar Baru

Sugiyono. 2010. Metode Penelitian Kuantitatif Kualitatif dan $R \& D$. Bandung: CV. Alfabeta

Soemarno Soedarmono, 2004. Character Bulding-Membentuk Karakter. Jakarta: PT. Elex Media Komputindo, Cetakan Ke-3

Yaumi, Muhammad. 2014. Pendidikan Karakter (Landasan Pilar dan Implementasi) Jakarta: Prenadamedia Grup

Zubaedi. 2011. Desain Pendidikan Karakter Konsepsi dan Aplikasi dalam Lembaga Pendidikan. Jakarta : Kencana

Undang-Undang Dasar Negara Indonesia Tahun 1945

Undang-Undang nomor 20 tahun 2003 tentang Sistem Pendidikan Nasional 
156 Integrasi Nilai-Nilai Pendidikan Karakter pada Setiap Mata Pelajaran di Tingkat SMPN, Sukri Badaruddin

Permendikbud, nomor 21 tahun 2016 tentang Standar Isi Satuan Pendidikan Dasar dan Menengah

Permendikbud, nomor 22 tahun 2016 tentang Standar Proses Satuan
Pendidikan Dasar dan

Menengah

http://rumahinspirasi.com/18-nilaidalam-pendidikan-karakterbangsa/diakses pada tanggal 19 Februari 2017. 